\title{
Pengembangan perangkat pembelajaran penemuan terbimbing untuk meningkatkan kemampuan berpikir kritis dan komunikasi matematis
}

\author{
Suparsih Suparsih \\ SMP Muhammadiyah 3 Yogyakarta. Jl. Kapten Piere Tendean No.19, Yogyakarta 55252, Indonesia \\ * Corresponding Author. E-mail: suparsih1269@yahoo.com \\ Received: 15 September 2018; Revised: 17 October 2018; Accepted: 21 December 2018
}

\begin{abstract}
Abstrak
Penelitian ini bertujuan menghasilkan perangkat pembelajaran matematika dengan pendekatan penemuan terbimbing untuk meningkatkan kemampuan berpikir kritis dan komunikasi matematis serta mendeskripsikan kualitas hasil pengembangan perangkat tersebut. Kualitas hasil pengembangan ditentukan berdasarkan pada kriteria dari Nieveen, yaitu valid, praktis, dan efektif. Penelitian ini merupakan penelitian pengembangan. Model pengembangan yang digunakan diadaptasi dari model Dick dan Carey. Adaptasi model Dick dan Carey menghasilkan 3 tahap pengembanan (define, design, dan develop). Subjek uji coba dalam penelitian ini adalah 60 siswa kelas 8 SMP Muhammadiyah 3 Yogyakarta. Instrumen yang digunakan antara lain lembar validasi, lembar penilaian dari guru dan siswa, lembar observasi keterlaksanaan pembelajaran, serta tes kemampuan berpikir kritis dan komunikasi matematis. Analisis data kevalidan dan analisis data kepraktisan masing-masing dilakukan dengan cara mengkonversi data kuantitatif berupa skor hasil penilaian menjadi data kualitatif berupa nilai standar skala lima. Analisis data keefektifan tes ketercapaian kompetensi dilakukan dengan cara menentukan persentase ketuntasan minimal, sedangkan analisis tes kemampuan berpikir kritis dan komunikasi matematis ditentukan peningkatannya. Hasil validasi ahli, penilaian dari guru dan siswa, observasi keterlaksanaan pembelajaran, dan hasil tes kemampuan berpikir kritis dan komunikasi matematis siswa memberikan bukti bahwa perangkat pembelajaran telah memenuhi kriteria valid, praktis, dan efektif.
\end{abstract}

Kata kunci: pengembangan, perangkat pembelajaran, penemuan terbimbing, berpikir kritis, komunikasi matematis.

\section{Developing instructional kits using the guided discovery to increase creative thinking and mathematical communication skills}

\begin{abstract}
This research is aimed to produced learning kits using guided discovery approach to increase the creative thinking and mathematical communication skills and to describe the quality of the result of the development. The quality of learning kits determined based on Nieveen's criteria, those are valid, practical, and effective. This research is development research adapted from Dick, and Carey model. The modified of this model resulted 3 stages of development steps (define, design, and develop). The subjects of this study are 60 grade 8 students of Muhammadiyah Junior High School 3 of Yogyakarta. The research instruments were validation sheet, assessment sheets from teacher and students, learning observation sheet, and critical thinking and mathematical communication skills test. The validity and practicality data analysis were done by converting the actual score into qualitative data with standard scale of five. The effectiveness of data analysis was done by determining the percentage of minimum completeness, while the analysis of critical thinking skills and mathematical communication tests determined the improvement. The results of experts' validation, assessments from teachers and students, learning observation, and critical thinking and mathematical communication skills test, provide the evidence that the learning kits are valid, practical and effective.
\end{abstract}

Keywords: development, learning media, guided discovery, critical thinking, mathematical communication.

How to Cite: Suparsih, S. (2018). Pengembangan perangkat pembelajaran penemuan terbimbing untuk meningkatkan kemampuan berpikir kritis dan komunikasi matematis. Pythagoras: Jurnal Pendidikan Matematika, 13(2), 214-224. doi:https://doi.org/10.21831/pg.v13i2.21240 


\section{PENDAHULUAN}

Permendikbud No. 65 tahun 2013, menyatakan bahwa proses pembelajaran pada satuan pendidikan diselenggarakan secara interaktif, inspiratif, menyenangkan, menantang, memotivasi peserta didik untuk berpartisipasi aktif, serta memberikan ruang yang cukup bagi prakarsa, kreativitas, dan kemandirian sesuai dengan bakat, minat, dan perkembangan fisik serta psikologis peserta didik (Mendikbud, 2013).

Proses pembelajaran matematika yang diinginkan adalah melatih peserta didik agar mampu berpikir kritis, logis dan kreatif, dapat bekerja jujur, disiplin dan penuh tanggung jawab. Dengan berbekal kemampuan tersebut, peserta didik diharapkan menjadi generasi yang tangguh dan siap menyongsong tantangan Abad 21. Kemampuan peserta didik yang diperlukan antara lain, kemampuan komunikatif, kritis, dan kreatif (Mendikbud RI, 2013)

Namun kenyataannya, pembelajaran matematika masih belum efektif dan menyenangkan. Pembelajaran matematika justru dianggap sebagai mata pelajaran yang sulit. Metode yang digunakan guru matematika diantaranya ceramah, tanya jawab, dan pemberian tugas. Metode ini menjadikan guru yang lebih aktif dibandingkan siswa (teacher center). Hal tersebut tidak sesuai dengan ketentuan bahwa proses pembelajaran dirancang dengan berpusat pada peserta didik untuk mendorong motivasi, minat, kreatifitas, inisiatif, inspirasi, kemandirian, dan semangat belajar (Mendikbud RI, 2016; Nicolic \& Cabay, 1999).

Materi aljabar merupakan salah satu materi yang diujikan dalam Ujian Nasional (UN) tahun 2013. Data hasil UN menunjukkan persentase daya serap siswa untuk materi aljabar masih rendah. Persentase penguasaan materi untuk aljabar pada tingkat nasional, tingkat propinsi DIY, dan tingkat kota Yogyakarta. Siswa di SMP Muhammadiyah 3 Yogyakarta, sebagai subyek penelitian, juga mengalami kendala pada materi tersebut. Sebanyak 293 peserta UN atau hanya 58,45\% siswa yang menguasai materi aljabar. Artinya, materi aljabar masih dirasa sulit oleh siswa.

Hasil observasi menunjukkan bahwa salah satu penyebab terjadinya hal tersebut adalah terbatasnya bahan ajar ataupun LKS untuk kegiatan pembelajaran matematika di kelas. Seperti yang diungkapkan oleh Prastowo (2011) bahwa guru hanya mengembangkan LKS pada materi tertentu saja. Akibatnya, perangkat pembelajaran yang tersedia masih sangat terbatas. Padahal, keter- sediaan perangkat pembelajaran merupakan salah satu hal penting yang mendukung kesuksesan pembelajaran (Djidu \& Retnawati, 2018; Retnawati, Djidu, Kartianom, Apino, \& Anazifa, 2018)

Salah satu alternatif solusi yang dapat dilakukan adalah guru menyiapkan perangkat dengan menggunakan pendekatan pembelajaran yang menyenangkan dan bermakna, yaitu pembelajaran yang mengaktifkan siswa dalam menemukan informasi, menganalisa dan mengkomunikasikan hasil temuannya. Salah satu pendekatan yang dapat digunakan adalah pembelajaran berbasis penyingkapan/ penyelidikan (discovery/ inquiry learning).

Pembelajaran berbasis penyingkapan/ penyelidikan matematika hendaknya dimulai dengan pengenalan masalah yang sesuai dengan situasi (contextual problem). Dengan mengajukan masalah kontekstual, peserta didik secara bertahap dibimbing untuk menguasai konsep matematika (Arroio, 2010; Deen, 2006; Gowri \& Missriya, 2015). Pembelajaran dengan penemuan terbimbing merupakan gabungan dua strategi belajar mandiri dan belajar bersama dalam usaha untuk membuat belajar menjadi lebih efisien untuk semua siswa. Pembelajaran dengan penemuan terbimbing atau discovery learning adalah proses pembelajaran yang mengutamakan pada penemuan konsep atau prinsip yang sebelumnya tidak diketahui.

Tabel 1. Sintaks Pembelajaran Guided Discovery

\begin{tabular}{|c|c|}
\hline Fase & Aktivitas Siswa \\
\hline 1. Pendahuluan & $\begin{array}{l}\text { Guru berusaha menarik } \\
\text { perhatian peserta didik terhadap } \\
\text { pelajaran. }\end{array}$ \\
\hline $\begin{array}{l}\text { 2. Fase } \\
\text { Terbuka }\end{array}$ & $\begin{array}{l}\text { Peserta didik memperhatikan } \\
\text { contoh dan membandingkan } \\
\text { contoh-contoh tersebut. }\end{array}$ \\
\hline $\begin{array}{l}\text { 3. Fase } \\
\text { Konvergen }\end{array}$ & $\begin{array}{l}\text { Peserta didik memperoleh } \\
\text { pertanyaan yang lebih spesifik } \\
\text { yang dirancang untuk } \\
\text { membimbing peserta didik } \\
\text { mencapai pemahaman tentang } \\
\text { konsep atau generalisasi. }\end{array}$ \\
\hline $\begin{array}{l}\text { 4. Penutup dan } \\
\text { Penerapan }\end{array}$ & $\begin{array}{l}\text { Peserta didik dibimbing untuk } \\
\text { memahami definisi suatu konsep } \\
\text { atau pernyataan generalisasi dan } \\
\text { peserta didik menerapkan } \\
\text { pemahaman mereka ke dalam } \\
\text { konteks baru. }\end{array}$ \\
\hline
\end{tabular}

Terdapat perbedaan antara inquiry/ penemuan dan discovery. Discovery menekankan pada penemuan konsep/prinsip yang sebelumnya 


\section{Pythagoras, 13 (2), 2018 - 216}

Suparsih Suparsih

tidak diketahui. Permasalahan yang dihadapi peserta didik pada pembelajaran discovery merupakan rekayasa guru, sedangkan pada inquiry/ penemuan masalah bukan rekayasa guru sehingga peserta didik harus mengerahkan seluruh pikir-an dan keterampilan untuk mendapatkan temuan-temuan masalah itu melalui penelitian (Gulo, 2002). Adapun sintaks atau langkah kegiatan pembelajaran dengan menggunakan guided discovery dapat dilihat pada Tabel 1.

Diantara beberapa kelebihan pembelajaran menggunakan pendekatan guided discovery Meskipun memiliki perbedaan, namun kedua pendekatan tersebut sama-sama efektif dalam meningkatkan motivasi belajar siswa. kemampuan berpikir kritis (Imawan, 2015), kemampuan berpikir kreatif (Rochani, 2016), dan kemampuan pemecahan masalah siswa (Khomsiatun \& Retnawati, 2015),. Prinsip-prinsip dalam guided discovery yang digunakan dalam model pembelajaran lain, seperti PBL, PJbL bahkan menjadi salah satu faktor yang mendukung peningkatan kemampuan berpikir siswa sampai pada level/ tingkat tinggi (Anazifa \& Djukri, 2017; Apino \& Retnawati, 2017; Djidu \& Jailani, 2017).

\section{Kemampuan Berpikir Kritis}

Pembelajaran matematika yang diharapkan dapat membentuk peserta didik berpikir kritis, menguasai konsep matematika dengan tuntas dan memperoleh nilai yang memuaskan. Menurut Duron, Limbach \& Waugh (2006), orang yang berpikir kritis mengangkat pertanyaan dan masalah yang penting, memformulasikannya dengan jelas, menyatukan dan menilai informasi yang relevan, menggunakan ide yang abstrak, berpikir terbuka, dan berkomunikasi dengan efektif dengan orang lain. Orang yang tidak berpikir kritis menderita keterbatasan dan egosentris dalam melihat dunia; mereka menjawab pertanyaan dengan ya atau tidak dan melihat pendapat mereka sebagai yang paling bijaksana dan fakta dari mereka sebagai yang paling relevan.

Berpikir kritis merupakan suatu karakteristik yang dianggap penting untuk diajarkan dan dapat dikembangkan melalui pembelajaran matematika karena matematika memiliki struktur dan keterkaitan yang kuat dan jelas antar konsep (Choy \& Oo, 2012; Lloyd \& Bahr, 2010; Fisher, 2009; dan Nitko \& Brookhart, 2011)

Aspek-aspek penting dalam berpikir kritis, diantaranya adalah: (1) Kemampuan seseorang untuk menemukan masalah, (2) Kemampuan menganalisis dan penalaran yang logis, (3) Ke- mampuan menerapkan metode/mengambil suatu kesimpulan.

\section{Kemampuan Komunikasi Matematis}

Mempelajari matematika tidak terbatas hanya mempunyai keterampilan berpikir rasional, logis, dan kritis tetapi juga harus mampu mengkomunikasikan secara matematis tentang konsep yang sedang dipelajari. Menurut Morreale, Osborn \& Pearson (2000) pembelajaran komunikasi penting untuk: (1) Komunikasi meningkatkan hubungan antara diri sendiri, orang lain, dan masyarakat, maka dari itu menjadi pusat pendidikan umum, (2) pendidikan komunikasi harus dimulai sejak dini dan berlanjut hingga pendidikan orang dewasa, (3) Pendidikan komunikasi meningkatkan berpikir kritis

Pembelajaran matematika umumnya dilakukan agar peserta didik dapat mengerti dan menjawab soal yang diberikan guru. Akan tetapi, peserta didik jarang bahkan tidak pernah dimintai penjelasan asal mula mereka mendapatkan jawaban. Peserta didik jarang sekali berkomunikasi dalam pembelajaran matematika, sehingga mereka sulit sekali untuk mengkomunikasikan kembali materi yang telah diberikan.

Komunikasi adalah bagian penting dalam matematika dan pembelajaran matematika. Ini adalah cara untuk berbagi ide dan mengecek pemahaman. Melalui komunikasi, ide menjadi objek refleksi, perbaikan, diskusi, dan perubahan. Proses komunikasi juga membantu membentuk pemahaman dan penetapan ide dan mengkomunikasikannya. Komunikasi dapat mendukung siswa dalam mempelajari konsep matematika yang baru, yang terlihat dalam situasi nyata, gambar, penggunaan objek, penjelasan, penggunaan diagram, menulis, dan penggunaan simbol matematika. Kesalahan pemahaman dapat ditemukan dan diselesaikan. Keuntungan lain adalah bahwa itu mengingatkan siswa bahwa mereka berbagi tanggung jawab dengan guru dalam pembelajaran (Morreale \& Osborn \& Pearson, 2000; NCTM, 2000).

Kemampuan komunikasi matematis meliputi tiga faktor, yaitu: (1) kemampuan menggunakan bahasa untuk menyatakan ide-ide, (2) kemampuan representasi matematika yang tepat untuk mengkomunikasikan penyelesaian masalah, (3) kemampuan menyampaikan penyelesaian masalah yang terstruktur dengan baik.

Mengingat pentingnya kemampuan berpikir kritis dan komunikasi matematis dan keterbatasan perangkat pembelajaran matematika, maka penelitian ini betujuan untuk menghasilkan 
perangkat pembelajaran matematika yang dapat memfasilitasi siswa untuk mengembangkan dua kemampuan tersebut sehingga pembelajaran matematika dapat berjalan dengan efektif. Perangkat pembelajaran yang dikembangkan mengunakan pendekatan penemuan terbimbing untuk meningkatkan kemampuan berpikir kritis dan komunikasi matematis siswa. Selain itu, mendeskripsikan kualitas perangkat pembelajaran yang dihasilkan juga menjadi tujuan pada penelitian ini.

\section{METODE}

Jenis penelitian ini adalah penelitian pengembangan menggunakan model pengembangan Dick, Carey, \& Carey (2001, pp.6-8) yang terdiri dari 10 langkah (lihat Tabel 2). Dari 10 langkah pengembangan tersebut, dimodifikasi sesuai dengan kondisi pada penelitian ini menjadi tiga langkah penelitian, yaitu tahap pendefinisian (define), tahap perancangan (design), tahap pengembangan (develop). Rincian modifikasi model pengembangan Dick \& Carey dapat dilihat pada Tabel 2.

Tabel 2. Modifikasi Model Pengembangan Dick \& Carey

\begin{tabular}{|c|c|c|}
\hline No. & $\begin{array}{l}\text { Model Pengembangan } \\
\text { Dick \& Carey }\end{array}$ & Hasil Modifikasi \\
\hline 1. & $\begin{array}{l}\text { Identity instructional } \\
\text { goals }\end{array}$ & \multirow{4}{*}{$\begin{array}{c}\text { Tahap } \\
\text { pendefinisian } \\
\text { (define) }\end{array}$} \\
\hline 2. & $\begin{array}{l}\text { Conduct instructional } \\
\text { analysis }\end{array}$ & \\
\hline 3. & $\begin{array}{l}\text { Analyze learners and } \\
\text { contexts }\end{array}$ & \\
\hline 4. & $\begin{array}{l}\text { Write performance } \\
\text { objectives }\end{array}$ & \\
\hline 5. & $\begin{array}{l}\text { Develop assessment } \\
\text { instruments }\end{array}$ & \multirow{2}{*}{$\begin{array}{l}\text { Tahap } \\
\text { perancangan } \\
(\text { design })\end{array}$} \\
\hline 6. & $\begin{array}{l}\text { Develop instructional } \\
\text { strategy }\end{array}$ & \\
\hline 7. & Develop and select & \multirow{4}{*}{$\begin{array}{c}\text { Tahap } \\
\text { pengembangan } \\
\text { (develop) }\end{array}$} \\
\hline 8. & $\begin{array}{l}\text { instructional material } \\
\text { Design and conduct } \\
\text { formative evaluation of } \\
\text { instruction }\end{array}$ & \\
\hline 9. & Revise instruction & \\
\hline 10. & $\begin{array}{l}\text { Design and conduct } \\
\text { summative evaluation }\end{array}$ & \\
\hline
\end{tabular}

Uji coba perangkat pembelajaran yang dikembangkan dilaksanakan di SMP Muhammadiyah 3 Yogyakarta. Subjek uji coba pada tahap pertama yaitu uji coba terbatas melibatkan 18 siswa dengan tingkat kemampuan tinggi, sedang dan rendah. Sedangkan uji coba tahap kedua yaitu uji coba lapangan dilaksanakan di kelas
VIII-1 dan VIII-2 SMP Muhammadiyah 3 Yogyakarta sebanyak 60 siswa.

Prosedur

Prosedur penelitian pengembangan model yang digunakan adalah model pengembangan Dick \& Carey yang telah dimodifikasi sesuai dengan kondisi pada penelitian ini. Dari sepuluh langkah pengembangan model Dick \& Carey, dimodifikasi menjadi tiga langkah penelitian, yaitu menentukan dan mendefinisikan kebutuhan pembelajaran (analisis kebutuhan, perumusan tujuan), perancangan perangkat pembelajaran, menghasilkan perangkat pembelajaran (validasi ahli, uji coba, revisi, dan produk akhir).

Pada tahap analisis kebutuhan dan perumusan tujuan, dilakukan pengumpulan informasi berkaitan dengan produk yang akan dikembangkan dengan cara kajian pustaka dan studi lapangan. Kajian pustaka dilakukan dengan mengumpulkan informasi yang berkaitan dengan mata pelajaran matematika materi aljabar, model pembelajaran, dan karakteristik siswa yang akan menjadi bahan perencanaan pembelajaran. Studi lapangan dilakukan dengan melakukan identifikasi masalah mendasar yang dibutuhkan dalam pengembangan model pembelajaran dan juga pengumpulan informasi berkaitan dengan RPP yang digunakan guru serta produk RPP yang sudah ada selama ini

Pada tahap desain/pengembangan produk, meliputi 4 macam kegiatan yaitu pemilihan format pembelajaran, perancangan perangkat pembelajaran, pemilihan media, dan pembuatan instrumen penelitian. Desain produksi yang dikembangkan meliputi RPP yang menggunakan model pembelajaran penemuan terbimbing dan Lembar Kerja Siswa (LKS).

Sebagaimana dikemukakan oleh Gulo, (2002); Kuhlthau, Maniotes, dan Caspari (2007); Eggen \& Kauchak (2012); dan Trianto (2014) bahwa sebuah model pembelajaran terdiri dari tahapan-tahapan pembelajaran (syntax), sistem sosial (social system), dan sistem pendukung (support system). Sintaks dideskripsikan sebagai urutan atau aktivitas dalam proses pembelajaran. Sistem sosial menguraikan tentang peranan guru dan siswa serta aturan-aturan yang diperlukan dalam interaksi pembelajaran. Sistem pendukung adalah kondisi yang diperlukan agar model pembelajaran dapat digunakan secara efektif dan efisien. Sistem pendukung dalam penelitian ini adalah Rencana Pelaksanaan Pembelajaran (RPP), dan Lembar Kerja Siswa (LKS). 


\section{Pythagoras, 13 (2), 2018 - 218}

Suparsih Suparsih

Untuk memenuhi kriteria pembelajaran dan kualitas produk yang baik pada penelitian ini dipakai kriteria kualitas produk menurut Nieveen. Nieveen (1999, pp.127) mengemukakan bahwa kualitas produk hasil desain, pengembangan, dan evaluasi program harus memenuhi tiga kriteria. Kriteria tersebut adalah valid, praktis, dan efektif.

Pada tahap uji coba produk, perangkat pembelajaran yang telah tersusun dilakukan proses validasi oleh ahli pendidikan matematika. Apabila valid dan layak dengan sedikit revisi, maka dilakukan revisi seperti yang disarankan oleh para ahli, dan draf yang direvisi dapat digunakan dalam uji coba.

Namun jika hasil analisis menunjukan tidak valid dan tidak layak, maka dilakukan revisi besar. Hasil revisi besar harus divalidasi kembali oleh ahli dan praktisi hingga didapat produk revisi yang valid dan layak. Selanjutnya diujicobakan pada kelompok terbatas yang dinamakan uji coba terbatas/uji coba skala kecil untuk menguji kualitas produk pengembangan pada skala kecil, yaitu untuk mengetahui keterbacaan dari produk pengembangan.

Apabila hasil dari uji coba terbatas yang dihasilkan menunjukkan kriteria yang telah ditentukan untuk uji coba keterbacaan, maka siap di uji cobakan. Tetapi jika hasil analisis belum menunjukkan kriteria yang telah ditentukan untuk uji coba keterbacaan, maka dilakukan perbaikan produk dan selanjutnya dilakukan uji coba lapangan. Hasil dari uji coba terbatas kemudian diujicobakan pada skala yang lebih luas, yaitu uji coba lapangan. Uji coba lapangan dilakukan dengan maksud untuk menguji kualitas produk yang dikembangkan yaitu perangkat pembelajaran yang berupa RPP dan LKS di sekolah yang menjadi subyek penelitian. Apabila hasil data analisis produk telah memenuhi kriteria kepraktisan dan keefektifan, maka produk

adalah produk akhir.

Pada tahap revisi produk, jika hasil analisis menunjukan perangkat pembelajaran belum memenuhi kriteria kepraktisan dan keefektifan, maka dilakukan revisi produk. Hasil revisi harus diujicobakan kembali hingga pada tahap akhir didapat produk perangkat pembelajaran yang valid, praktis dan efektif.

\section{Instrumen}

Instrumen yang digunakan dalam penelitian ini meliputi: instrumen validasi format untuk mengetahui kevalidan instrumen yang akan digunakan dalam penelitian, instrumen penilaian kevalidan yang terdiri dari lembar validasi RPP, LKS, tes hasil belajar. Penilaian Kepraktisan terdiri dari lembar penilaian guru terhadap produk pengembangan, lembar penilaian siswa, dan lembar observasi keterlaksanaan pembelajaran. Instrumen penilaian keefektifan terdiri dari tes hasil belajar, tes kemampuan berpikir kritis, dan tes kemampuan komunikasi matematis.

\section{Teknik Analisis Data}

Analisis data penelitian dilakukan untuk membuktikan validitas, kepraktisan dan keefektifan perangkat pembelajaran. Data yang diperoleh dari ahli dianalisis untuk mengetahui apakah produk pengembangan sudah dikatakan valid ditinjau dari kekuatan landasan teoritis. Sedangkan data hasil uji coba lapangan digunakan untuk menjawab kualitas kepraktisan dan keefektifan pembelajaran yang dikembangkan. Langkahlangkah yang dilakukan untuk memenuhi kriteria tersebut meliputi:

Tabel 3. Pedoman Konversi Skor Aktual Menjadi Skor Skala Lima

\begin{tabular}{ccc}
\hline Interval & Kriteria & Nilai \\
\hline$M_{i}+1,8 S D i<\bar{M}$ & Sangat baik & A \\
$M_{i}+0,8 S D i<\bar{M} \leq M_{i}+1,8 S L$ & Baik & B \\
$M_{i}-0,8 S D i<\bar{M} \leq M_{i}+0,8 S L$ & Cukup & C \\
$M_{i}-1,8 S D i<\bar{M} \leq M_{i}-0,8 S L$ & Kurang & D \\
$\bar{M} \leq M_{i}-1,8 S D i$ & Sangat Kurang & E \\
\hline
\end{tabular}

Keterangan:

$\bar{M}=$ Rata-rata akhir

$M i=$ Rata-rata ideal $=1 / 2$ (skor maksimum ideal + skor minimum ideal)

$\mathrm{SDi}=$ Standar deviasi ideal $=1 / 6$ (skor maksimum ideal - skor minimum ideal)

Skor maksimal ideal $=\Sigma$ butir kriteria $\times$ skor tertinggi Skor minimum ideal $=\Sigma$ butir kriteria $\times$ skor terendah (Direktorat Pembinaan SMA, 2010, pp. 59-60)

Pertama, analisis kevalidan dilakukan untuk mengetahui tingkat kevalidan perangkat pembelajaran pada materi aljabar. Langkah-langkah yang digunakan untuk memberikan kualitas kevalidan terhadap produk yang dikembangkan adalah (1) Data berupa skor penilaian validator yang diperoleh melalui lembar validasi diubah menjadi data interval. Dalam lembar validasi disediakan lima pilihan untuk memberikan penilaian tentang kualitas produk yaitu sangat kurang (nilai 1), kurang (nilai 2), cukup (nilai 3), baik (nilai 4), dan sangat baik (nilai 5). (2) Mengkonversi data skor penilaian menjadi nilai skala lima. Skor yang diperoleh dari validator dijumlahkan menjadi skor aktual. Untuk melihat kategorisasi skor digunakan acuan kategorisasi yang tertera pada Tabel 3 . 
Pythagoras, 13 (2), 2018 - 219

Suparsih Suparsih

Produk yang dikembangkan dikatakan valid jika hasil penilaian dari ahli memperoleh kategori minimal baik (B) dan hasil kesimpulan umum dari penilaian ahli menyatakan bahwa perangkat layak digunakan dengan revisi (LDR) atau layak digunakan (LD). Apabila kategori LDR, maka dilakukan revisi sesuai dengan masukan validator.

Kedua, analisis kepraktisan diperoleh dari data penilaian guru terhadap produk, data tanggapan peserta didik terhadap proses pembelajaran dan pemanfaatan LKS serta data observasi terhadap keterlaksanaan model pembelajaran penemuan terbimbing. Kualitas praktis dari penilaian ini diperoleh jika guru memberikan penilaian tentang produk pengembangan model pembelajaran penemuan terbimbing. pada materi aljabar di SMP yang dikembangkan dengan kategori minimal baik (B), peserta didik memberikan penilaian terhadap proses pembelajaran dan pemanfaatan LKS dengan kategori minimal baik (B), dan Hasil penilaian dari pengamatan yang dilakukan oleh observer (pengamat) pada setiap pembelajaran memiliki kualitas praktis jika persentase keterlaksanaan pembelajaran minimal $80 \%$. Jika tingkat pencapaian di bawah $80 \%$ maka perlu dilakukan revisi berdasarkan pengamatan yang dilakukan dan diskusi dengan guru.

Ketiga, analisis kualitas keefektifan produk pengembangan diperoleh apabila persentase hasil tes hasil belajar siswa pada materi aljabar dengan menggunakan model pembelajaran penemuan terbimbing memenuhi kriteria ketuntasan belajar secara klasikal yaitu minimal $80 \%$.

Keempat, estimasi reliabilitas, dan pembuktian validitas perangkat tes hasil belajar. Analisis yang dilakukan bertujuan untuk mengetahui daya pembeda, tingkat kesulitan, analisis distraktor dan memperoleh estimasi reliabilitas instrumen tes hasil belajar. Untuk mengestimasi reliabilitas tes hasil belajar, digunakan rumus Cronbach Alpha (Allen \& Yen, 1979, pp. 83-84) sebagai berikut.

$\propto=\left[\frac{N}{N-1}\right]\left[\frac{\sigma_{\mathrm{x}-\sum_{\mathrm{i}=1}^{\mathrm{N}} \sigma_{\mathrm{Y}_{\mathrm{i}}}^{2}}^{2}}{\sigma_{\mathrm{x}}^{2}}\right]$

dan

$K R 20=\left[\frac{\mathrm{N}}{\mathrm{N}-1}\right]\left[1-\frac{\sum_{\mathrm{i}=1}^{\mathrm{N}} \mathrm{p}_{\mathrm{i}}(1-\mathrm{pi})}{\sigma_{\mathrm{x}}^{2}}\right]$

Keterangan:

$\mathrm{N}$ = banyaknya komponen (item).

$\sigma_{x}^{2}=$ varian skor tes.

$\sigma_{Y_{i}}^{2}=$ varian skor butir ke $i$

$\mathrm{P}_{\mathrm{i}}=$ proporsi jawaban benar

\section{HASIL DAN PEMBAHASAN}

Tahap pertama, analisis kebutuhan dan perumusan tujuan. Hasil telaah terhadap kebutuhan dan perumusan tujuan adalah masih banyak peserta didik yang belum dapat menyelesaikan soal yang berkaitan dengan aljabar. Hasil telaah terhadap struktur kurikulum menunjukkan bahwa materi aljabar terdapat di dalam materi kelas VIII semester 1 dan 2. Hasil telaah terhadap perangkat pembelajaran matematika SMP ditemukan bahwa dalam menyusun RPP guru lebih sering mengadopsi produk MGMP atau mengunduh (download) dari internet.

Berdasarkan hasil telaah kurikulum SMP dengan memperhatikan cakupan materi serta teori belajar yang sesuai sehingga diperoleh pendekatan pembelajaran yang cocok dengan karakter siswa SMP untuk digunakan dalam pembelajaran aljabar model pembelajaran penemuan terbimbing. model pembelajaran penemuan terbimbing dipilih karena menggunakan masalahmasalah kontekstual dan melibatkan siswa secara aktif. Di akhir diharapkan dapat meningkatkan hasil belajar matematika siswa.

Menurut hasil analisis siswa, pada umumnya usia siswa SMP/MTs adalah 12-15 tahun. Menurut teori Bruner, perkembangan kognitif siswa SMP merupakan tahap proses aktif dimana siswa membangun (mengkonstruksi) pengetahuan baru berdasarkan pengalaman/ pengetahuan yang sudah dimilikinya. Di rentang usia ini karakteristik siswa telah mampu diajak berpikir abstrak namun belum sempurna. Sehingga untuk menanamkan konsep masih diperlukan demonstrasi atau presentasi nonverbal. Pengalaman juga tidak kalah penting dalam proses pembelajaran sehingga belajar adalah proses mengkonstruksi pengetahuan yang pernah dialami. Oleh karena itu LKS yang dikembangkan dalam penelitian ini menampilkan masalah-masalah sehari-hari yang tidak asing bagi siswa serta menggunakan pendekatan penyelidikan dengan harapan siswa mengalami proses menemukan suatu konsep/ informasi.

Secara umum siswa SMP Muhammadiyah 3 Yogyakarta mempunyai kemampuan akademik yang beragam, yaitu kategori atas, kategori menengah dan kategori rendah di kabupaten kota Yogyakarta. Kemampuan akademik siswa yang menjadi kelas uji coba lapangan yaitu kelas VIII1 dan kelas VIII-2 SMP Muhammadiyah 3 Yogyakarta tahun pelajaran 2015-2016 secara akademik memiliki kemampuan yang beragam terdiri dari siswa yang memiliki kemampuan 
kategori atas, kategori menengah dan kategori bawah.

Perangkat pembelajaran yang dikembangkan dalam penelitian ini mengacu pada materi aljabar. Rincian materi disusun secara sistematis, penyusunan materi disesuaikan dengan urutan kompetensi inti dan kompetensi dasar. Urutan materi disajikan dari menerapkan operasi aljabar yang melibatkan bilangan rasional; menentukan nilai variabel persamaan linear dua variabel dalam konteks nyata; menentukan persamaan garis lurus dan grafiknya; menyajikan fungsi dalam berbagai bentuk relasi, pasangan berurut, rumus fungsi, tabel, grafik, dan diagram; membuat dan menyelesaikan model matematika dari masalah nyata yang berkaitan dengan persamaan linear dua variabel.

Analisis tugas bertujuan untuk menentukan tugas yang akan disampaikan pada siswa sehingga diharapkan siswa memiliki kemampuan menyelesaikan masalah pada materi aljabar yang disesuaikan dengan kebutuhan untuk meningkatkan kemampuan berpikir kritis dan komunikasi matematis siswa, sehingga indikator peningkatan kemampuan berpikir kritis dan komunikasi matematis disusun dan diimplementasikan bersamaan dengan indikator ketercapaian KI/KD. Secara lebih rinci tugas yang dilakukan oleh siswa pada materi pokok menerapkan operasi aljabar yang melibatkan bilangan rasional; menentukan nilai variabel persamaan linear dua variabel dalam konteks nyata; menentukan persamaan garis lurus dan grafiknya; menyajikan fungsi dalam berbagai bentuk relasi, pasangan berurut, rumus fungsi, tabel, grafik, dan diagram; membuat dan menyelesaikan model matematika dari masalah nyata yang berkaitan dengan persamaan linear dua variabel.

Spesifikasi tujuan pembelajaran merupakan dasar penyusunan rancangan perangkat pembelajaran dan penyusunan tes hasil belajar. Tanpa disadari konsep aljabar seringkali dipakai dalam kehidupan sehari-hari. Konsep aljabar digunakan untuk menyelesaikan beberapa kasus dalam kehidupan, misalnya untuk menjumlah, mengurangi, mengalikan, membagi dan seterusnya.

Dengan kegiatan diskusi kelompok dalam pembelajaran aljabar ini diharapkan siswa terlibat aktif dalam kegiatan pembelajaran dan bertanggungjawab dalam menyampaikan pendapat, menjawab pertanyaan, memberi saran dan kritik serta siswa dapat menerapkan operasi aljabar yang melibatkan bilangan rasional; menentukan nilai variabel persamaan linear dua variabel dalam konteks nyata; menentukan persamaan garis lurus dan grafiknya; menyajikan fungsi dalam berbagai bentuk relasi, pasangan berurut, rumus fungsi, tabel, grafik, dan diagram; membuat dan menyelesaikan model matematika dari masalah nyata yang berkaitan dengan persamaan linear dua variabel.

Adapun tujuan pembelajaran untuk aspek afektif diharapkan setelah pembelajaran selesai adalah membangun sikap kerjasama, kerja keras, dan kepedulian terhadap lingkungan dan orang lain, dan mengembangkan rasa ingin tahu siswa.

Tahap kedua yaitu desain/ pengembangan produk. Setelah memperhatikan hasil analisis materi, analisis siswa, analisis tugas, spesifikasi tujuan pembelajaran maka dapat ditentukan format pembelajaran yang dikembangkan dengan pendekatan saintifik dan model pembelajaran Penemuan Terbimbing untuk meningkatkan kemampuan berpikir kritis dan komunikasi matematis siswa. Produk dari penelitian pengembangan perangkat pembelajaran penemuan terbimbing ini terdiri dari Rencana Pelaksanaan Pelajaran (RPP), dan Lembar Kerja Siswa (LKS).

Tahap ketiga yaitu uji coba produk. Rencana Pelaksanaan Pelajaran (RPP), dan Lembar Kerja Siswa (LKS) yang telah disusun kemudian dilakukan proses validasi ahli pendidikan matematika. Hasil validasi ahli berupa masukan dan saran yang disampaikan meliputi saran tentang tata tulis, materi pembelajaran, format perangkat, dan kebahasaan.

Tabel 4. Hasil Validasi Ahli

\begin{tabular}{ccc}
\hline \multirow{2}{*}{ Validator } & \multicolumn{2}{c}{ Skor } \\
\cline { 2 - 3 } & RPP & LKS \\
\hline 1 & 140 & 122 \\
2 & 146 & 115 \\
Jumlah skor & 143 & 118,5 \\
Nilai & B & B \\
Kategori & Valid & Valid \\
\hline
\end{tabular}

Berdasarkan hasil penilaian ahli terhadap produk pengembangan model pembelajaran penemuan terbimbing dapat ditunjukkan bahwa produk yang dihasilkan termasuk kategori valid/ baik. Hasil penilaian terhadap produk pengembangan dapat dilihat pada Tabel 4 .

Data yang ditunjukkan pada Tabel 4 memperlihatkan bahwa skor nyata untuk RPP 143 berada pada rentang skor $119<\mathrm{x}<147$ maka RPP kategori valid. Skor nyata untuk LKS 118,5 berada pada rentang skor $102<\mathrm{x}<126$ sehingga LKS kategori valid. Jika produk penelitian yang dikembangkan mempunyai kategori minimal baik, maka produk penelitian memenuhi kualitas valid. Tabel 4 menunjukkan bahwa hasil validasi 
Pythagoras, 13 (2), 2018 - 221

Suparsih Suparsih

Rencana Pelaksanaan Pelajaran (RPP), dan Lembar Kerja Siswa (LKS) dari dua validator menunjukkan nilai B dengan kategori valid/ baik, sehingga produk termasuk dalam kriteria Layak Digunakan dengan Revisi (LDR) yang berarti bahwa produk memenuhi syarat dapat digunakan.

Perangkat pembelajaran yaitu LKS materi aljabar dengan model penemuan terbimbing yang telah divalidasi ahli, kemudian diujicobakan secara terbatas kepada 18 siswa untuk diminta membaca dan memberikan komentar tentang perangkat pembelajaran, kemudian mengisi lembar panduan keterbacaan. Siswa memberikan catatan tentang petunjuk pengerjaan LKS yang kurang dipahami dan kalimat pada soal cerita yang dianggap kurang efektif.

Perangkat pembelajaran yang telah direvisi diujicobakan kepada 60 siswa (kelas VIII-1 30 siswa dan kelas VIII-2 30 siswa) SMP Muhammadiyah 3 Yogyakarta. Uji coba lapangan ini menghasilkan data yang dianalisis untuk mengetahui kepraktisan dan keefektifan perangkat pembelajaraan yang dikembangkan. Kepraktisan dapat diketahui dari lembar penilaian guru dan penilaian siswa serta lembar observasi keterlaksanaan pembelajaran. Sedangkan keefektifan dapat dilihat dari hasil tes prestasi belajar.

Tabel 5. Hasil Penilaian Guru

\begin{tabular}{ccc}
\hline \multirow{2}{*}{ Guru } & \multicolumn{2}{c}{ Skor } \\
\cline { 2 - 3 } & RPP & LKS \\
\hline 1 & 38 & 38 \\
2 & 32 & 33 \\
Skor nyata & 35 & 35,5 \\
Nilai & A & A \\
Kategori & Sangat Praktis & Sangat Praktis \\
\hline
\end{tabular}

Data yang ditampilkan pada Tabel 5 menunjukkan bahwa penilaian guru terhadap perangkat pembelajaran telah mencapai kategori sangat praktis (A). Oleh karena itu, perangkat pembelajaran yang dihasilkan memenuhi kriteria yang ditetapkan sehingga layak untuk digunakan. Selain penilaian guru, penilaian 60 siswa terhadap kepraktisan LKS diperoleh skor 58,73. Skor ini termasuk dalam kategori sangat praktis. Oleh karena itu, LKS yang dikembangkan memenuhi kriteria kepraktisan.

Selanjutnya, kepraktisan analisis data juga dilakukan terhadap data keterlaksanaan pembelajaran pada setiap pertemuan. Keterlaksanaan pembelajaran diamati oleh observer yang merupakan guru mitra. Hasil observasi keterlaksanaan pembelajaran dapat dilihat pada Tabel 6 .
Tabel 6. Hasil Analisis Data Observasi Keterlaksanaan Pembelajaran

\begin{tabular}{ccr}
\hline Pertemuan ke & Skor & Persentase \\
\hline 1 & 18 & $90 \%$ \\
2 & 19 & $95 \%$ \\
3 & 19 & $95 \%$ \\
4 & 15 & $75 \%$ \\
\hline
\end{tabular}

Berdasarkan hasil penilaian guru, penilaian siswa dan data observasi keterlaksanaan pembelajaran dengan pendekatan Penemuan Terbimbing maka perangkat pembelajaran dinyatakan memenuhi kriteria praktis.

Selanjutnya, keefektifan produk pengembangan dapat dilihat dari tes hasil belajar untuk kemampuan berpikir kritis dan komunikasi matematis siswa. Data hasil tes hasil belajar, diikuti oleh 60 siswa yang terdiri dari kelas VIII-1 dan VIII-2. Data hasil tes prestasi belajar disajikan pada Tabel 7.

Tabel 7. Hasil Tes Kemampuan Berpikir Kritis

\begin{tabular}{ccccc}
\hline Kelas & $\begin{array}{c}\text { Rata-rata } \\
\text { skor }\end{array}$ & Tuntas & $\begin{array}{c}\text { Belum } \\
\text { tuntas }\end{array}$ & $\begin{array}{c}\text { Jumlah } \\
\text { siswa }\end{array}$ \\
\hline VIII- 1 & 84,27 & 25 & 5 & 30 \\
VIII- 2 & 85,80 & 25 & 5 & 30 \\
Total & 85,04 & 50 & 10 & 60 \\
\hline
\end{tabular}

Data pada Tabel 7 menunjukkan bahwa ketuntasan klasikal untuk kemampuan berpikir kritis mencapai 50 siswa dari jumlah total 60 siswa atau mencapai $83,33 \%$, dan untuk kemampuan komunikasi matematis mencapai 52 siswa dari total 60 siswa atau mencapai $84,17 \%$, sehingga melebihi batas minimal $75 \%$. Sedangkan nilai rata-rata klasikal mencapai untuk kemampuan berpikir kritis 85,04 , dan rata-rata klasikal untuk kemampuan komunikasi matematis 85,07 sehingga melebihi KKM yaitu 75. Oleh karena itu, dapat disimpulkan bahwa perangkat pembelajaran berbasis penemuan terbimbing yang dikembangkan mencapai kategori efektif ditinjau dari hasil belajar siswa.

Tabel 8. Data Hasil Tes Kemampuan Komunikasi Matematis siswa

\begin{tabular}{ccccc}
\hline Kelas & $\begin{array}{c}\text { Rata-rata } \\
\text { skor }\end{array}$ & Tuntas & $\begin{array}{c}\text { Belum } \\
\text { tuntas }\end{array}$ & $\begin{array}{c}\text { Jumlah } \\
\text { siswa }\end{array}$ \\
\hline VIII- 1 & 84,27 & 24 & 6 & 30 \\
VIII- 2 & 85,87 & 28 & 2 & 30 \\
Total & 85,07 & 52 & 8 & 60 \\
\hline
\end{tabular}

Tahap berikutnya adalah revisi produk. Revisi perangkat pembelajaran aljabar dengan pendekatan penemuan terbimbing untuk meningkatkan kemampuan berpikir kritis dan komunikasi matematis dilakukan sebanyak tiga kali. 
Revisi pertama dilakukan setelah tahap validasi. Revisi kedua dilakukan setelah uji coba terbatas, dan revisi ketiga dilakukan setelah uji coba lapangan. Selanjutnya kajian produk akhir. Menurut Nieveen (1999, p. 126), produk pengembangan yang berkualitas harus memenuhi kriteria kevalidan, kepraktisan dan keefektifan.

Pertama, kevalidan perangkat pembelajaran. Berdasarkan penilaian para ahli, produk akhir perangkat pembelajaran matematika SMP yang berbasis penemuan terbimbing pada materi pokok aljabar yang terdiri dari rencana pelaksanaan pembelajaran (RPP) dan lembar kegiatan siswa (LKS) yang telah dikembangkan sudah memenuhi kriteria valid karena perangkat pembelajaran tersebut disusun mengacu kepada metodologi pembelajaran yang mengacu pada pendekatan pembelajaran konstruktivis yang berdasarkan pada proses pencarian informasi (guided discovery/ penemuan terbimbing ).

Perangkat pembelajaran hasil pengembangan juga telah direvisi berdasarkan masukan dan saran dari ahli, guru mitra dan siswa sehingga diperoleh perangkat pembelajaran yang layak untuk digunakan.

Kedua, kepraktisan perangkat pembelajaran. Berdasarkan uji lapangan diperoleh hasil penilaian dari guru mitra dan siswa terhadap perangkat pembelajaran yang telah dikembangkan dan sudah mencapai kriteria praktis. Kriteria praktis terpenuhi berdasarkan penilaian guru yang mempraktekkan perangkat pembelajaran secara langsung dengan kategori praktis. Di samping itu kategori praktis terpenuhi berdasarkan penilaian siswa yang mengikuti pembelajaran dikelas secara langsung yang menunjukkan kategori praktis. Kriteria praktis selanjutnya diperoleh berdasarkan pada tingkat keterlaksanaan pembelajaran dengan kategori praktis. Dengan demikian secara keseluruhan kriteria kepraktisan perangkat pembelajaran yang dikembangkan telah terpenuhi.

Ketiga, keefektifan perangkat pembelajaran. Berdasarkan uji coba lapangan yang telah dilaksanakan secara umum menunjukkan bahwa perangkat pembelajaran yang dihasilkan telah memenuhi kategori efektif. Hasil uji coba telah menunjukkan kriteria efektif ditinjau dari hasil tes hasil belajar untuk kemampuan berpikir kritis yang memperoleh ketuntasan $83,33 \%$ siswa, dan untuk kemampuan komunikasi matematis yang memperoleh ketuntasan $84,17 \%$ telah mencapai KKM.

Berdasarkan kriteria kevalidan, kepraktisan, dan keefektifan perangkat pembelajaran yang dikembangkan telah terpenuhi, maka diperoleh suatu produk akhir perangkat pembelajaran matematika SMP materi aljabar dengan pendekatan penemuan terbimbing yang valid, praktis, dan efektif sehingga layak digunakan untuk pembelajaran di sekolah.

Efektivitas dari perangkat pembelajaran yang dihasilkan ini tentu tidak terlepas dari pendekatan pembelajaran yang digunakan. Seperti yang telah disebutkan pada pendahuluan, bahwa pembelajaran penemuan terbimbing memang memiliki keunggulan untuk mengembangkan berbagai kemampuan matematika siswa, seperti kemampuan berpikir kritis (Imawan, 2015; Nuriyatin \& Hartono, 2016), berpikir kreatif (Rochani, 2016), kemampuan pemecahan masalah siswa (Khomsiatun \& Retnawati, 2015), bahkan menjadi salah satu faktor yang mendukung peningkatan kemampuan berpikir siswa sampai pada level/tingkat tinggi (Anazifa \& Djukri, 2017; Apino \& Retnawati, 2017; Djidu \& Jailani, 2017; Sutrisno \& Retnawati, 2015).

\section{SIMPULAN}

Setelah melalui 3 tahapan pengembangan, dihasilkan perangkat pembelajaran matematika SMP materi aljabar dengan pendekatan penemuan terbimbing yang terdiri dari 4 RPP, 4 LKS, dan satu perangkat tes hasil belajar pada kompetensi aljabar. Hasil validasi perangkat pembelajaran menunjukkan bahwa bahwa perangkat pembelajaran yang dihasilkan telah memenuhi kriteria valid. Selain itu, hasil penilaian guru, siswa, dan hasil observasi keterlaksanaan pembelajaran memberikan hasil bahwa perangkat pembelajar yang dihasilkan praktis dalam penggunaannya. Selanjutnya, uji coba pelaksanaan pembelajaran menunjukkan bahwa perangkat pembelajaran yang dihasilkan terbukti efektif ditinjau dari kemampuan berpikir kritis dan kemampuan komunikasi matematis siswa.

\section{DAFTAR PUSTAKA}

Allen, M. J., \& Yen, W. M., (1979). Introduction to measurement theory. Monterey, CA: Brooks/Cole Publishing Company.

Anazifa, R. D., \& Djukri. (2017). Project-based learning and problem-based learning: are they effective to improve student's thinking skills? Jurnal Pendidikan IPA Indonesia, 6(2), 346-355. https://doi.org/10.15294/jpii.v6i2.11100

Apino, E., \& Retnawati, H. (2017). Developing instructional design to improve 
mathematical higher order thinking skills of students. Journal of Physics: Conference Series, 812, 1-7. https://doi.org/10.1088/17426596/755/1/011001

Arroio, A. (2010). Context-based learning: A role for cinema in science education. Science Education International, 21(3), 131-143

Choy, S. C. \& Oo, P. S. (2012). Reflective thinking and teaching and teaching practices: a precursor for incorporating critical thinking into the classroom?. International Journal of Instruction, 5 (1), July 2012, p-ISSN:1964-609X: Malaysia.

Deen, I. S, (2006). Contextual teaching and learning practices in the family and consumer sciences curriculum. Journal of Family and Consumer Science Education, 24(1), Spring/Summer: University of Georgia.

Dick, W., Carey, L., \& Carey, J. O. (2001). The systematic design of instruction, $6^{\text {th }}$ edition. Florida: Pearson.

Direktorat Pembinaan SMA. (2010). Juknis Penyusunan Perangkat Penilaian Afektif SMA. Jakarta

Djidu, H., \& Jailani, J. (2017). Aktivitas pembelajaran matematika yang dapat melatih kemampuan berpikir tingkat tinggi siswa. PRISMA, Prosiding Seminar Nasional Matematika, 1(1), 312-321. Retrieved from https://journal.unnes.ac.id/sju/index.php/p risma/article/view/21614

Djidu, H., \& Retnawati, H. (2018). Cultural values-integrated mathematical learning model to develop HOTS and character values. In E. Retnowati, A. Ghufron, Marzuki, Kasiyan, A. C. Pierawan, \& Ashadi (Eds.), Character Education for 21 st Century Global Citizens: Proceedings of the 2nd International Conference on Teacher Education and Professional Development (INCOTEPD 2017) (pp. 361-370). Yogyakarta: Routledge. Retrieved from https://www.taylorfrancis.com/books/978 1138099227

Duron, R., Limbach, B., \& Waugh, W. (2006). Critical thinking framework for any discipline. International Journal of Teaching and Learning in Higher
Education, $\quad$ 17(2), ISSN

$1812-$

9129:http://www.isetl.org/ijtlhe.

Eggen, P., \& Kauchak, D. (2012). Strategie and model for teachers: teaching content anf thinking skills. Boston, MA: Pearson Education Inc.

Fisher, A. (2009). Berpikir kritis. Jakarta: Erlangga. Alih bahasa oleh Binyamin Hadinata.

Gowri, M., \& Missiriya, M. A. S. (2015). Context based learning: Introducing newer learning approach in nursing. International Journal of Pharma and Bio Sciences. 6(4), (B) 7276

Gulo. W (2002). Strategi belajar mengajar. Jakarta: Grasindo.

Imawan, O. R. (2015). Perbandingan antara keefektifan model guided discovery learning dan project-based learning pada matakuliah geometri. PYTHAGORAS: Jurnal Pendidikan Matematika, 10(2), 179-188.

Khomsiatun, S., \& Retnawati, H. (2015). Pengembangan perangkat pembelajaran dengan penemuan terbimbing untuk meningkatkan kemampuan pemecahan masalah. Jurnal Riset Pendidikan Matematika, 2(1), 92-106. Retrieved from https://journal.uny.ac.id/index.php/jrpm/ar ticle/view/7153/6170

Kuhlthau, C. C., Maniotes, L. K. \& Caspari, A. K. (2007). Guided inquiry: Learning in the 21 st century school. New York: Libraries Unlimited

Lloyd, M. \& Bahr, N. (2010). Thinking critically about critical thinking in higher education. International Journal for The Scholarship of Teaching and Learning IJ-SOTL, 4 (2), Art. 9: Brisbane, Queensland, Australia.

Mendikbud RI. (2013). Permendikbud RI Nomor 81A Tahun 2013 Tentang Implementasi Implementasi Kurikulum.

Mendikbud RI. (2016). Lampiran Peraturan Menteri Pendidikan dan Kebudayaan Republik IndonesiaNomor 21 Tahun 2016 Tentang Standar Isi.

Morreale, S. P., Osborn, M. M., \& Pearson, J. C. (2000). Why communication is important: a rationale for the centrality of the study of communication. Journal of the Association for Communication Administration, 29(2000), 1-25. 


\section{Pythagoras, 13 (2), 2018 - 224}

Suparsih Suparsih

NCTM. (2000). Principles and standards for school mathematics. Reston, Virginia: The National Council of Teachers of Mathematics, Inc.

Nicolic, V., \& Cabay, H. (1999). Am I teaching well? Self-evolution strategies for effective teachers. Toronto: Pippin.

Nieveen, N. (1999). Prototyping to reach product quality. London: Kluwer Academic Publisher.

Nitko, A. J., \& Brookhart, S. M. (2011). Educational assessment of students (6 ${ }^{\text {th }}$ ed.). Boston: Pearson.

Nuriyatin, S., \& Hartono, H. (2016). Pengembangan pembelajaran penemuan terbimbing untuk meningkatkan berpikir kritis dan motivasi belajar geometri di SMP. PYTHAGORAS: Jurnal Pendidikan Matematika, 11(2), 207-218. https://doi.org/10.21831/pg.v11i2.10656

Prastowo, A. (2011). Panduan kreatif membuat bahan ajar inovatif. Yogyakarta: DIVA Press.

Retnawati, H., Djidu, H., Kartianom, K., Apino,
E., \& Anazifa, R. D. (2018). Teachers' knowledge about higher-order thinking skills and its learning strategy. Problem of Education in the 21 st Century, 76(2), 215230. Retrieved from http://oaji.net/articles/2017/4571524597598.pdf

Rochani, S. (2016). Keefektifan pembelajaran matematika berbasis masalah dan penemuan terbimbing ditinjau dari hasil belajar kognitif kemampuan berpikir kreatif. Jurnal Riset Pendidikan Matematika, 3(2), 273-283. https://doi.org/10.21831/jrpm.v3i2.5722

Sutrisno, D., \& Retnawati, H. (2015). Komparasi pendekatan penemuan terbimbing dalam pembelajaran kooperatif think pair share dengan two stay two stray. PYTHAGORAS: Jurnal Pendidikan Matematika, 10(1), 15-27. https://doi.org/10.21831/pg.v10i1.9093

Trianto. (2014). Mendesain model pembelajaran inovatif, progresif, dan kontekstual. Jakarta: Prenadamedia Group. 